\title{
CLASSIFIED NOTICES
}

Straight copy ads only. Box number service is not available for personnel vacancies; the name and address of the agency must appear. Rate is $\$ 2$. per line. Closing date six weeks before month of issue.

CALIFORNIA-_STAFF PSYCHIATRIST: Position includes directing clinical, consultative, in-service training, coordinating, and public equcation activities. Outpatient services only. Requires a valid physicians' and surgeons' license to practice in the State of California. Short-Doyle Clinic serving population of 150,000 in Pomona Valley. Full-time and part-time staff of 50 . Salary, $\$ 1976$ to $\$ 2411$ per month. For additional information contact: Sidney R. Simms, Personnel Director, City of Pomona, Pomona, Calif. 91769. Phone: (714) 620-2291.

CANADA - Child Psychiatrist, certified, required for an established group of seven psychiatrists provid. ing a comprehensive mental health service in this community. He would be expected to take charge of existing out-patient children's services, a Learning and Development Clinic, provide individual and g:oup psychotherapy and develop in-patient children's services. Salary negotiable. Reply to: Psychiatric Consultants, 160 King Street South, Waterloo, Ontario. Attention: (Mrs.) D. Schanzenbacher, Office Co-ordinator.

MARYLAND-NURSE SUPERVISORS-Mental health and generalized service that includes home nursing in a county of 700,000 near Washington, D.C. Salary range $\$ 11,431-\$ 15,017$ per year. State merit system and excellent fringe benefits. Requires Bachelor's degree and courses in administration, supervision and consultation or in clinical specialty for which applying and three years experience as a public health nurse. EOE. Reply to Personnel Office, 773-1400 ext. 313, Prince George's County Health Department, Cheverly, Maryland.

MICHIGAN_PSYCHIATRISTS: Full or Part Time. Young Adult Institute, Detroit, Michigan a multi-disciplined psychiatric program for youths, has opening for Psychiatrists on a 20 or 40 hour per week basis. Program has in-patient facility and community centers covering Northwest and Northeast Detroit. Salary according to qualifications. $\$ 25,000$ to $\$ 30,000$ per year for full time position. Excellent fringe benefits provided by Michigan Civil Service. Call or write: M. Kemal Goknar, M.D., Director, Young Adult Institute, 1151 Taylor, 4th Floor, Detroit, Michigan 48202. Phone: 224-6882. AN EQUAL OPPORTUNITY EMPLOYER.

NEW YORK-Psychiatrist for child caring institution. Experience working with children and adolescents. Part-Time. Send resume to Personnel Dept., Mission of the Immaculate Virgin, Mount Loretto, Staten Island, New York 10309.

NEW YORK - THE ADVANCED INSTITUTE FOR ANALYTIC PSYCHOTHERAPY is currently accepting registration for the spring term of 1974. The institute is incorporated under the N.Y. State Education Law, and is affiliated with the Jamaica Center for Psychotherapy, a N.Y. State licensed psychiatric clinic. The Institute offers a program of courses, case seminars and treatment experience under supervision, leading to a certificate, with the objective of giving each candidate a thorough understanding of the theory and practice of modern analytic psychotherapy. After the first year, opportunity is given to Institute students to work for remuneration at Jamaica Center for Psychotherapy. Write to: Joseph LeBoit, Dean of Training, Advanced Institute for Psychotherapy, 178-10 Wexford Terrace, Jamaica Estates, N.Y. 11432.

TEXAS-The Bexar County Mental Health Mental Retardation Center in San Antonio, Texas, is seeking staff psychiatrists to function in neighborhood mental health centers being operated through community agencies. Resources in the field of medical education are present, with state-supported medical, dental and nursing schools located in the greater city area. In addition to the educational resources, San Antonio is rapidly developing into one of the leading medical centers in the Southwestern United States. The projected medical and economic growth for the area makes San Antonio one of the most exciting and opportunity-filled cities in the Southwest. If interested in becoming a part of a committed staff, contact Mr. James F. Bailey, ACSW, Executive Director of the Bexar County MHMR Center, 611 North Flores, San Antonio, Texas 78205-(512) 225-4011. An equal opportunity employer.

CONNECTICUT_Executive Director. Long established child guidance clinic undergoing reorganization. Serves population over 300,000. AAPCC member. MSW or PhD psychology. At least 3 years experience in supervision and administration, preferably in mental health setting. Challenging opportunity for person with demonstrated community and clinic organization skills to provide leadership in developing programs responsive to local needs. Duties include direct service. Salary minimum: $\$ 16,000$. Will be commensurate with experience. Write Per. sonnel Committee, Child Guidance Clinic of Greater Bridgeport, 1081 Iranistan Avenue, Bridgeport, Connecticut 06604.

MICHIGAN_Administrative Coordinator. Position available for individual with mental health background, with emphasis on administrative skills. Bachelor of Science degree required; Master's degree desirable. Primary responsibility centers administrative management of newly developed Mental Health Department. Contact Robert H. Selby, Personnel Director, Emma L. Bixby Hospital, Adrian, Michigan 49221. Telephone 313-263-0711, Ext. 426.

MICHIGAN_-Day Hospital Coordinator. Position available for MSW, or individual with Master's level psychology background. Knowledge of mental health, preferably with experience in the Day Hospital concept, or certainly experience in a Mental Health Clinic. Competitive salary with excellent fringe benefits. Contact Dr. Joseph Casagrande, Department of Mental Health, Emma L. Bixby Hospital, Adrian. Michigan 49221. Telephone 313-263-0711, Ext. 423. 
MICHIGAN_Psychologist. Position available for individual with Master's level clinical psychology background. Experience in mental health setting preferred, but not required. Primary duties will involve diagnostic evaluation and treatment (children and adult) within state supported community mental health program. Competitive salary, excellent fringe benefits. Contact Dr. Joseph Casagrande, Department of Mental Health, Emma L. Bixby Hospital, Adrian, Michigan 49221. Telephone 313-263-0711, Ext. 423.
MICHIGAN--Social Worker. Position available for MSW. Experience in mental health setting preferred but not mandatory. Primary duties involve outpatient psychotherapy (individual and/or group) within state supported community mental health program. Program includes 16 bed in-patient unit of 262 bed General Hospital. Competitive salary, excellent fringe benefits. Contact Dr. Joseph Casagrande, Department of Mental Health, Emma L. Bixby Hospital, Adrian, Michigan 49221. Telephone 313-263-0711, Ext. 423.

an important followup study of institutional treatment . . . neu'ly published by CIVLA

\title{
Continuity and Support Following Residential Treatment
}

\author{
By Delores A. Taylor and Stuart W. Alpert
}

This study of 75 children discharged from a residential program was expressly concerned with the postdischarge conditions necessary to transfer and maintain the gains they achieved during placement. It gives weighty evidence to the emerging practice $w$ isdom that without maximal inclusion of the parents throughout the child's treatment experience, all its value may be lost. This is a necessary addition to the literature on institutional care and residen. tial treatment. I-35. $\$ 3.50$ per copy.

Please order by code number and title. Orders under $\$ 5$ must be prepaid with 10\% added for postage and handling.

Child Welfare League of America - 67 Irving Place - New York, N.Y. 10003 